\title{
グルタチオンによるアミノ配糖体耳毒性軽減
}

\author{
西田功

\section{Aminoglycoside Ototoxicity Reduced by Glutathione in Guinea Pigs}

\author{
Isao Nishida \\ (WFAC Hiroshima General Hospital)
}

\begin{abstract}
Aminoglycoside antibiotics are commonly used in the treatment of serious gram negative infections despite a high incidence of associated ototoxicity. Attempts to elucidate the mechanism of the toxicity or prevent the adverse effects have so far been unsuccessful. Recently the damaging effects of aminoglycoside on the inner ear have been shown to be caused by a metabolite of the drug, implying an enzymatic conversion of the parent compound and glutathione has been suggested to be closely related to the mechanism of detoxication of this metabolite. This study demonstrates the attenuation of aminoglycoside ototoxicity by glutathione. Guinea pigs were given amikacin or amikacin + glutathione by intramuscular injection. Pretreatment with glutathione significantly reduced damage to the outer hair cells of the organ of Corti. This finding suggests that glutathione can reduce aminoglycoside ototoxicity and that it can be considered for clinical use.
\end{abstract}

Key words : ototoxicity, amikacin, glutathione, the organ of Corti

\section{はじめに}

アミノ配糖体系薬剤のよく知られた副作用の 1 つとし て，内耳ならびに腎毒性があり112)，これらの副作用の 発現のため，アミノ配糖体系薬剂の使用範囲が限定され ているのが実状である。なかでも，耳毒性は，腎毒性が 可逆的であり治療によく反応するのに対して，非可逆的 であり, 永続的な聴力障害や前庭機能障害を引き起こし， アミノ配糖体系薬剤を臨床的に使用寸るにあたっての大 きな問題となっている.

耳毒性の発現には様々な要素が関係して物り，障害の 強さは薬剂の種類だけではなく, 薬剤の投与期間, 総投 与量，投与方法などが密接に関与している．これらの点 に関して，著者らは，すでにアミノ配糖体系薬剤の種類 により，その耳毒性の発現頻度，程度に差が認められる こと，同一薬剤でも 1 日総投与量が同じ場合には，1 日 1 回投与の方が 1 日 2 回投与に比較して, 耳毒性の軽減 が得られることを明らかにした3) 6).
しかし，投与方法，薬剤の種類により耳毒性は軽減す るものの，完全にこの副作用を予防することは実現され ていない，そのため, 従来より，アミノ配糖体系薬剤の 耳毒性を軽減するために，ホスホマイシン7)，セファラ

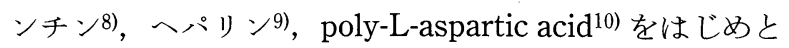
して, 様々な薬剤, 方法が試みられてきたが, いずれも 満足なものとは言い難いのが現状である。今回，著者は， グルタチオンの生体内, 特に内耳, 腎での解毒作用に注 目し11) 13)，この薬剤によるアミノ配糖体系薬剤の耳毒 性軽減の可能性を検討したので報告する.

\section{研究方法}

実験には体重 350 500 g プライエル反射正常の成熟, 有色モルモット20匹を使用した。動物は投与方法により 4 群に分類した。 I 群 ( 5 匹) は硫酸アミカシン (AMK) $200 \mathrm{mg} / \mathrm{kg}$ を 1 日 1 回筋注, II群 ( 5 匹) はグルタチオ ソ $200 \mathrm{mg} /$ bodyを 1 日 1 回筋注, III 群 ( 5 匹) は AMK 
$200 \mathrm{mg}$ を 1 日 1 回筋注に加えて,グルタチオン $200 \mathrm{mg} /$ bodyを AMK 投与30分前に計28日間筋注した。 N 群 ( 5 匹）はコントロールとして生理食塩水を同様に筋注した. 最終投与後24時間にて，これらの動物をネンブタール深 麻酔下に，左心室より $2.5 \%$ グルタールアルデヒド $(0.1$ $\mathrm{M}$ リン酸緩衝, $\mathrm{pH}$ 7.4) にて潅流固定後, 側頭骨摘出, 中耳骨胞解放後, 同液にて内耳潅流を行った。試料は, さらに24時間同液にて浸漬固定を行った後に，コルチ器 を取りだし $2 \%$ タンニン酸，2\%オスミウム酸にて導電 染色後, エタノール系列にて脱水, 酢酸イソアミルにて 置換後, 臨界点乾燥 $\left(\mathrm{CO}_{2}\right)$ を行い, 白金スパッターュー ティングを行い，走査電顕用試料とした。尚，観察には Hitachi S800 形走査電子顕微鏡を使用した。

蝸牛コルチ器有毛細胞の障害程度は, Johansson $5^{14)}$ の分類を参考に Grade 1〜3 そ分類した。すなわち, Grade 1 以有毛細胞聴毛の10～50\%の変性脱落をみたも の, Grade 2 は有毛細胞聴毛の 50 ～100\%の変性, 脱落 で一部正常な聴毛の残存しているもの, Grade 3 は有毛 細胞聴毛の完全脱落を示したものとした(図 1 )。正円空 から 1 18 mm の部位でのコルチ器を, 各々 $1 \mathrm{~mm}$ ずつ

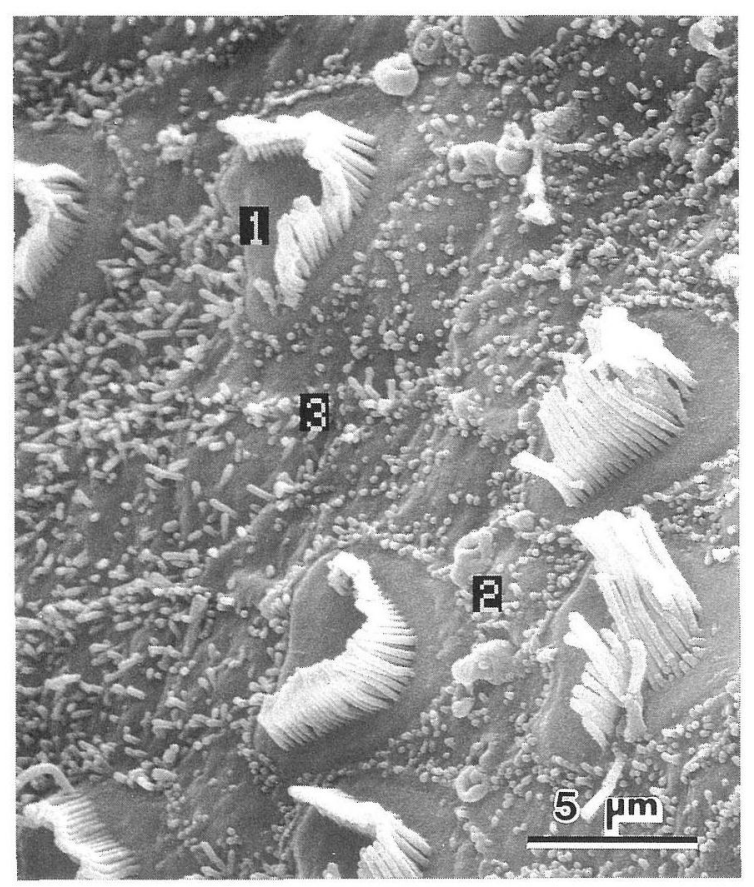

図1螖牛コルチ器有毛細胞の走查電子顕微鏡像 Grade 1，2，3 示す.
の部位に分け, 蝸牛全回転を観察の後, 各部位での内有 毛細胞(約120個), 外有毛細胞(約450個)の障害程度を, 内有毛細胞，外有毛細胞第 1 列，第 2 列，第 3 列飞分け, 先の分類に従い検索し，その割合を統計処理した3).

\section{結果}

4 群の有毛細胞聴毛障害を, 先の Grade に従い詳細 に観察し障害の程度を比較した、コントロール群ならび にグルタチオン単独投与群に执いては組織学的に正常で 内外有毛細胞の障害は特に認められなかった(図 2)。し かしながら AMK 単独投与群执よび AMK+グルタチ オン投与群に和いては僅かの有毛細胞聴毛の脱落からコ ルチ器すべての破壞といったような様々な程度の障害を 認めた。

AMK 単独投与群では内外有毛細胞聴毛の脱落，变性 といった高度の障害が認められ，軽度障害も含めると外

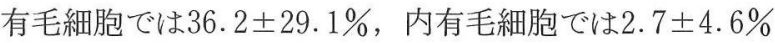
の障害を呈した。さらに AMK 投与群に扬ける外有毛 細胞の障害の程度は下方回転により強く，上方回転に向

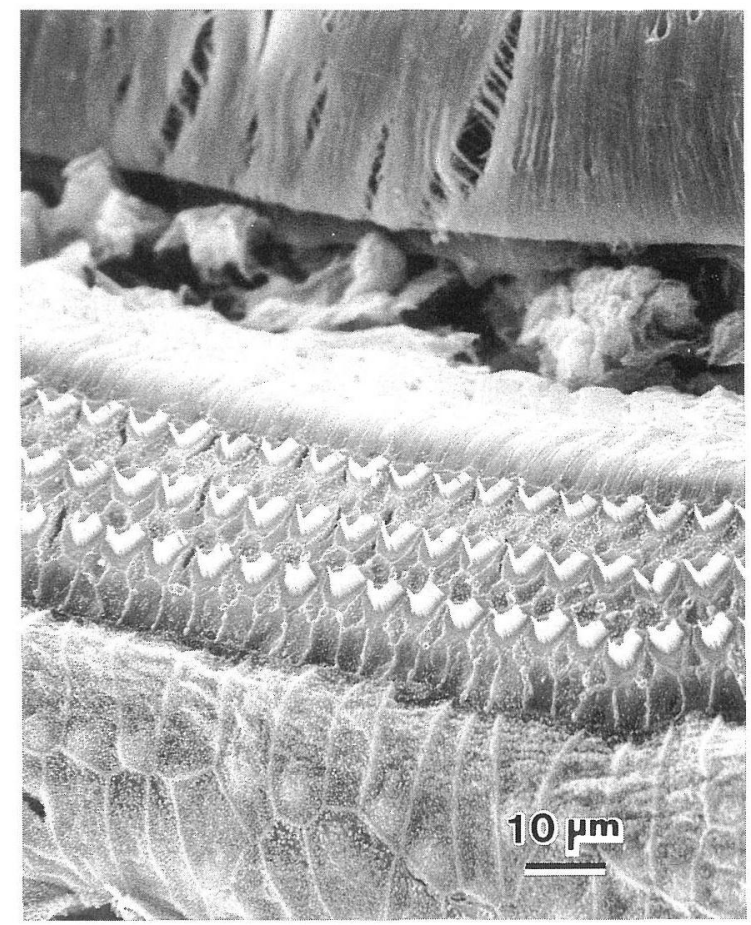

図 2 コントロール群の蝸牛コルチ器有毛細胞の走査電子顕微 鏡像

内外有毛細胞の障害は認められない。 
からにつれて弱くなる傾向が認められた。また，その障 害の程度は第 1 列に強く $(46.6 \pm 31.5 \%), 2$ 列(34.2 $31.3 \%), 3$ 列 $(27.9 \pm 25.4 \%)$ の順に軽度になっていた。 しかし, 内有毛細胞に和ける障害は外有毛細胞に比較し て非常に軽度でコントロール群との比較でも大きな差は 認められなかった(図 3〜5).

$\mathrm{AMK}+$ グルタチオン投与群では, AMK 単独投与群 飞比較して内外有毛細胞, 特に外有毛細胞の障害は軽度 で，その障害の割合は外有毛細胞で10.6土3.6\%, 内有 毛細胞で2.9土3.6\%といずれ女基底回転でわずか汇認め られるのみであった．特に，Grade 3 の高度障害を示し た細胞の割合は AMK 単独投与群では外有毛細胞の $27.0 \pm 25.5 \%$ であったのに対して, $\mathrm{AMK}+$ グルタチオ ン投与群では1.78土1.15\%と明らかに減少していた。さ らに Grade $1+2$ の軽度障害を示した細胞の割合は AMK 単独投与群では外有毛細胞の $9.32 \pm 4.21 \%$ に比較 して AMK+グルタチオン投与群では $5.88 \pm 3.30 \%$ と 相対的に軽度の障害が多く認められた。障害様式に関し てはAMK 単独投与と異なり, 障害の程度が全般的に



図 3 AMK 単独投与群の走査電子顕微鏡像 (正円空上り 7 $\mathrm{mm}$ の部分)

外有毛細胞に和いて聴毛の完全脱落を示した細胞 (Grade 3) が著明に認められる(

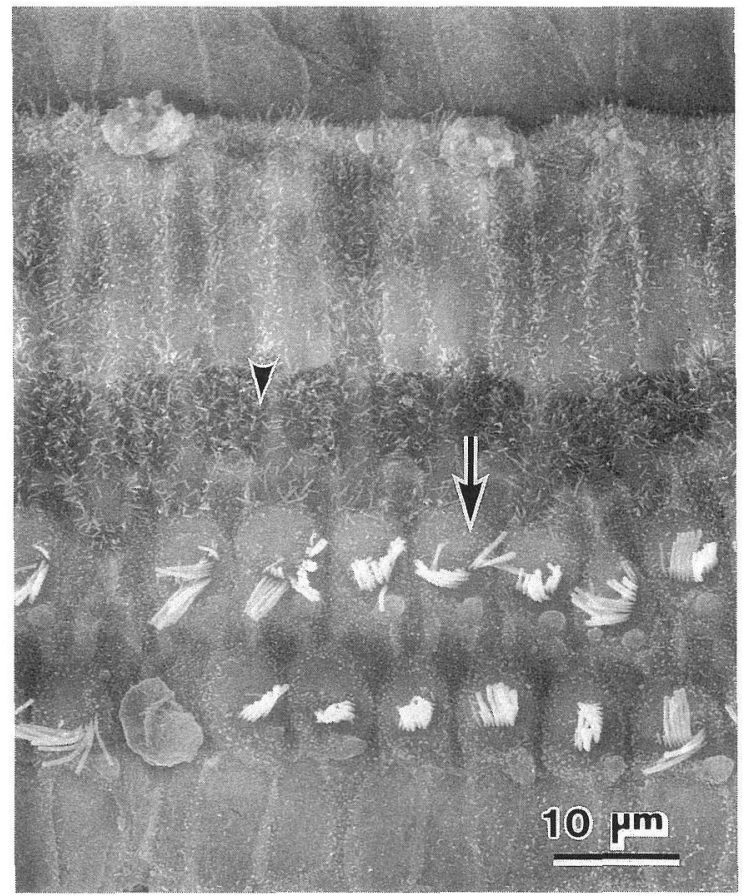

図 4 AMK 単独投与群の走査電子顕微鏡像 (正円空より 17 $\mathrm{mm}$ の部分)

上方回転に拈いてもGrade $3(\boldsymbol{V})$, Grade $2($ )などの 強い障害を認める。障害の程度は外有毛細胞 1 列が最 も強く 2 列 3 列の順に軽くなっている.

軽いためか，基底回転で障害の程度が強かったものの， 各列間の比較ではその障害率は外有毛細胞第 1 列で6.8 $\pm 5.0 \%$ ，第 2 列で $5.9 \pm 2.5 \%$ ，第 3 列で $10.3 \pm 5.7 \%$ と 明らかな差は認められなかった(図 $6 〜 8$ ).

以上の内外有毛細胞障害の程度を統計処理 (Student's T-test) し，検定を行った、AMK+グルタチオン投与 群では, AMK 単独投与群に比較して外有毛細胞に拈い て有意に $(\mathrm{p}<0.05)$ 障害の程度が軽減していた（図 9$)$. 内訳をみると $\mathrm{AMK}+$ グルタチオン投与群では, $\mathrm{AMK}$ 単独投与群に比較して有意に $(\mathrm{p}<0.05)$ Grade 3 の高度 障害を示した細胞の割合が減少していたが Grade 1+2 の軽度障害を示した細胞の割合には有意差は認められな かった(図10).

\section{考察}

今日，多くの抗生物質が開発される中，アミ八配糖体 系薬剤は，その広い抗菌スペクトルム，特にグラム陰性 桿菌に対する抗菌力により, 重症感染症や耐性菌感染症 



図 $5 \mathrm{AMK}$ 単独投与群に扩ける蝸牛コルチ器有毛細胞の障害 程度のグラフ

（綎軸は障害の割合 $(\%)$ ，横軸は正円空 (R.W. ) からの 距離を示す)

$\mathrm{OHC}$; 外有毛細胞 (数字は列), IHC; 内有毛細胞

に対して，一般臨床上使用する機会の多い抗生剂である. しかし，その副作用として，腎毒性および耳毒性を有し ていることにより臨床使用上，使用範囲が限定されてい るのが実状である。そこで, これらの副作用の少ないア ミ, 配糖体系薬剂の開発が進められ，ネチルマインンや イセパミシンといらた腎毒性，耳毒性の少ない薬剂が開 発されてきたが，まったく腎毒性，耳毒性を持たないア ミ, 配糖体系薬剤は開発されていない。そのため, これ らの副作用を軽減させる方法の検討も極めて重要であり, これまでにも，アミノ配糖体系薬剂の投与量, 投与経路, 投与方法の検討がなされてきた。その結果, 最近では, アミノ配糖体系薬剤の投与方法において，1 日総投与量 が同じ場合は，1 日 1 回投与の汇らが 1 日 2 回，3 回の

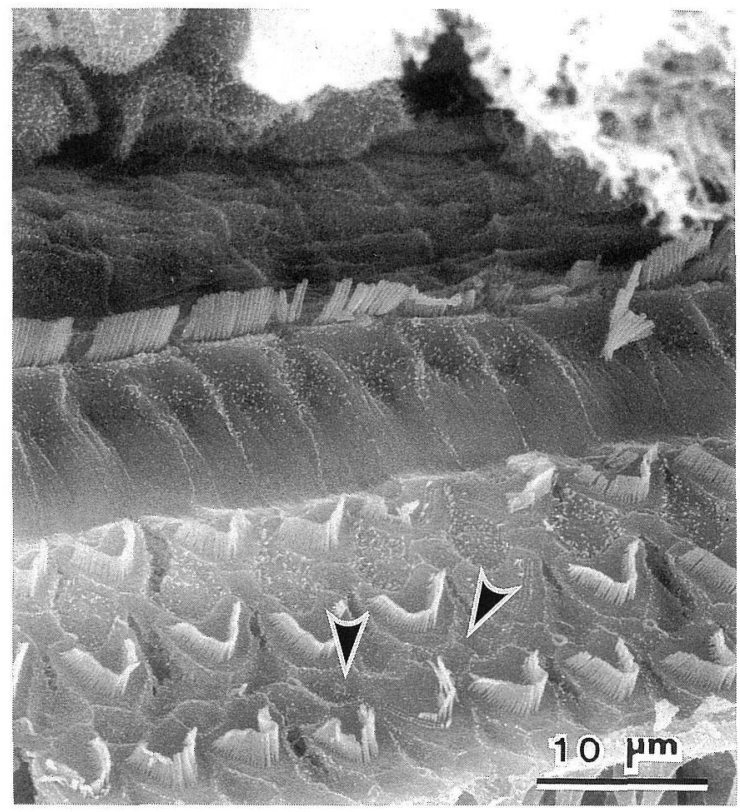

図 $6 \mathrm{AMK}+$ グルタチオン投与群の走査電子顕微鏡像 $($ 正円空 より $4 \mathrm{~mm}$ の部分）

外有毛細胞に軽度の聴毛の障害 Grade 1, 2( 济)を認め る。

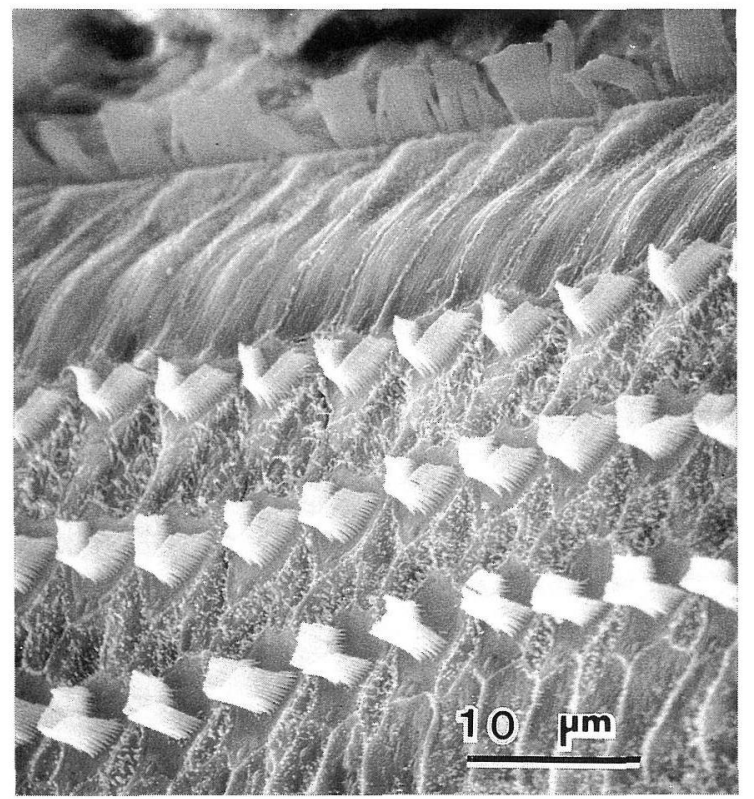

図 $7 \mathrm{AMK}+$ グルタチオン投与群の走査電子顕微鏡像 (正円空 より $10 \mathrm{~mm}$ の部分)

上方回転では有毛細胞の障害は汪とんど認められない。 

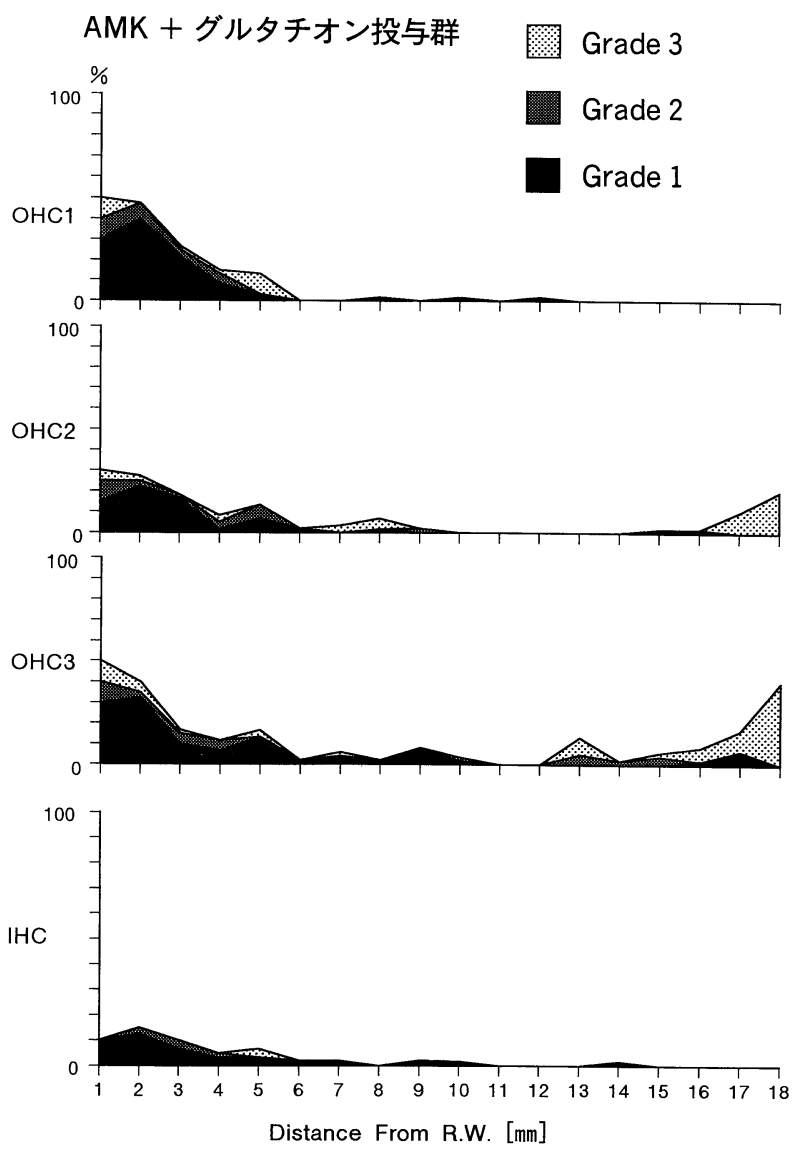

図 $8 \mathrm{AMK}+$ グルタチオン投与群に打ける蝸牛コルチ器有毛 細胞の障害程度のグラフ

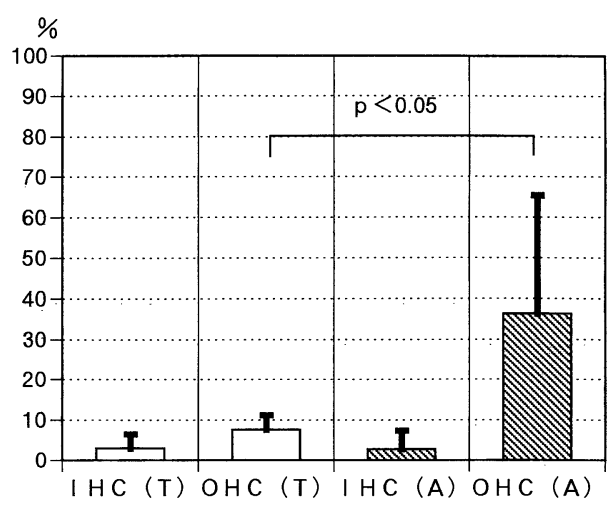

図 $9 \mathrm{AMK}$ 単独投与群と $\mathrm{AMK}+$ グルタチオン投与群に括け る内外有毛細胞障害 (Grade 1+2+3) の割合

縦軸; 平均十標準偏差 $(\%),(\mathrm{A}) ; \mathrm{AMK}$ 単独投与群, (T) ; $\mathrm{AMK}+$ グルタチオン投与群, $\mathrm{OHC}$; 外有毛細胞, IHC ; 内有毛細胞

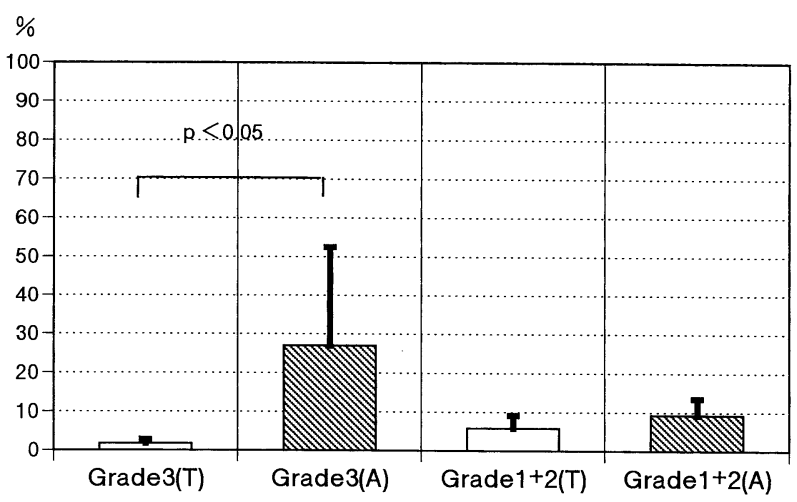

図10 AMK 単独投与群と $\mathrm{AMK}+$ グルタチオン投与群に括け る外有毛細胞障害の Grade 別の割合

縦軸; 平均十標準偏差 $(\%),(\mathrm{A}) ; \mathrm{AMK}$ 単独投与群, $(\mathrm{T}) ; \mathrm{AMK}+$ グルタチオン投与群

分割投与に比べて, 有意に耳毒性の発現が軽減すること が明らかとなっている3) 6).ささらに，あるいはホスホマ イシン7)，セファランチン8)， ヘパリン9)などの種々の薬 剤による腎臓毒性, 耳毒性の軽減についての試みがなさ れてきたが，薬剤による耳毒性の予防といった試みは成 果を上げていない，具体的には，近年，ホスホマイシン によりラットに扣いて腎, 内耳毒性の軽減効果が認めら れたとの報告がなされ，耳毒性軽減への期待が高まって いたが，家鬼に扮いてはホスホマイシンによる耳毒性の 軽減作用が認められず7)，セファランチンでは，耳毒性 の軽減効果がアミノ配糖体系薬剤の投与量が少ない場合 には認められない8)など効果にばらつきがあり，へパリ ンでは，カナマイシンに対しては耳毒性軽減作用を有す るけれども, ゲンタシンでは耳毒性軽減効果が認められ ない9)など, 現在のところ, 臨床的に耳毒性の予防に使 用できるかどらかは不明である。そこで，これらの薬剤 による耳毒性軽減効果の機序について考察してみると, セファランチン, ホスホマイシンの作用の一部は膜の安 定化78)，へパリンではカナマイシンとへパリンの結合9), またホスホマイシンでは，アミノ配糖体系薬剤の腎への 蓄積抑制作用が主な作用之考光られて招り，いずれも直 接的な耳毒性の障害予防とはなっていない。これらのこ とから考光ると，アミノ配糖体系薬剂の耳毒性の発現機 序に対して，それを直接的に阻害する方法の検討がなさ れるべきであると考えられる。

アミノ配糖体系薬剤による耳毒性の発現機序について は, 従来より様々な検討がなされている15)16). 現在, ア 
ミノ配糖体系薬剤による耳毒性の発現機序には 2 つのこ とが考光られている. 第1のものは, アミノ配糖体系薬 剂々のものが，細胞外あるいは細胞内の一定の部位に直 接作用することにより生じる, 急性で可逆性の障害であ る17). 臨床の場で，アミノ配糖体系薬剤投与後，一過性 の耳鴂やめまいなどを訴光ることが時にあるが，このよ らな急性の内耳障害はこの機構によるものと考兄られる. この障害は, 具体的にはアミノ配糖体系薬剂による外有 毛細胞をはじめとする内耳感覚細胞細胞膜の, カルシウ ムイオンの置換と電位依存性カルシウムチャンネルの阻 害により生じるものとされている18). この機序は, ウシ ガエル球形囊の感覚細胞で認められたストレプトマイシ ンによる興奮伝達チャンネルの阻害と同様のものであり, in vivo での実験で可逆性であることが明らかになって いる19)。この作用に関連するアミノ配糖体系薬剤のレセ プターとしては, 細胞膜の細胞質側で phosphatidylinositol-1, 4-biphosphate が関与していることが報告されてお り1720), 先に述べたセファランチンあるいはホスホマイ シンなどの薬剤の作用の一部はこの機構を阻害すること により, 耳毒性の軽減を計っているものと考兄られる.

しかし，この理論のみでアミノ配糖体系薬剂の耳毒性 のすべてを説明することはできない，例えば，動物実験 あるいは実際の臨床例に执いて, 薬剤の投与終了後もか なりの長期間にわたって内耳障害が進行して行く，いわ ゆる delayed ototoxicity が認められること21)，あるいは， in vivo の実験で内耳, 腎を障害するアミノ配糖体系薬 剂が in vitro で単離蝸牛外有毛細胞や腎細胞を非可逆性 に障害しないことが示されて抢り22) 24), その理由は不 明であった. そこで，第 2 の障害機序が提唱されること となる、従来, アミノ配糖体系薬剤はその大部分が, 体 内よりそのままの形で回収されることから生体内で大き な代謝を受けないとされてきた25)。しかしながら，近年， 放射性トレーサーを使用した研究に上り生体内に投与し たアミノ配糖体系薬剤が, 体内で代謝され代謝産物が生 成されることが明らかとなってきた26). 加光て，アミ， 配糖体系薬剤の一種であるゲンタマイシンの投与により， 肝細胞細胞基質より約 $500 \mathrm{Da}$ の分子量をるつ耳障害性 の代謝産物が得られること，この代謝産物の主な作用は， 病的な興奮伝達チャンネルの解放による $\mathrm{K}^{+}$イオンの細 胞内への流入であることなどが解明された。 これらによ り，アミノ配糖体系薬剤が耳毒性を発現する機序として, アミノ配糖体系薬剂が生体内で代謝され，その代謝産物
の作用により耳毒性を起こすといら第 2 の説が提唱され るよらになった。ささらに，ゲンタマイシン以外のアミ， 配糖体系薬剤であるトブラマイシンやカナマイシンも同 様の代謝産物を生成することより，この機構はアミノ配 糖体系薬剤に共通したものであるといら認識がなされる ようになってきた(15)27).

ここで，アミノ配糖体系薬剤の代謝経路について考光 てみると，いまだ完全には明らかになっていないものの， これまでの古典的な解析の方法では, 耳毒性を引き起こ す代謝産物が検出できなかったことから考光ると, 生体 内での代謝産物の濃度はその耳毒性の強さにもかかわら ず比較的低いことが推測される。一般に，薬剤の代謝の 主なものは，肝蔵でなされるが，他の組織も関与してい ることが知られている ${ }^{28)}$. 実際, 内耳へのアミノ配糖体 系薬郕の直接投与 $\left.{ }^{29}\right)$ や内耳の細胞を組織培養しその中 にアミノ配糖体系薬剤を投与することでも耳毒性が生じ ること30)より，内耳でもアミノ配糖体系薬剤の代謝が 行われていると考兄られ，内耳，腎でもアミノ配糖体系 薬剂の毒性代謝産物は生成されるものと推察される ${ }^{15)}$.

つぎに，アミノ配糖体系薬剤が特異的に内耳，腎を障 害することに関して考兵てみると, 解毒作用の面で藏器 間に受傷性の差が存在することが原因と考光られる。例 えば, 肝臓は, グルクロン酸抱合, SH 化合物との結合 による薬剤の解毒を行う主要な臓器であり31), アミノ配 糖体系薬剤によって障害を受けない蔵器である。これは， 肝藏では生成されたアミノ配糖体系薬剂の毒性代謝産物 はその大部分が解毒され，一定のレベル以下に留まって いるためと考兄られる. 一方, 腎, 内耳に执いては, こ の解毒作用が肝臓に比較して弱く, その結果代謝産物の 濃度が一定のレベルを超えた場合には，毒性を発現する と考光られる。

アミノ配糖体系薬剤の解毒作用に，主要な役割をはた している物質の 1 つにグルタチオンがあげられている12). グルタチオンは, 細胞内に比較的多量に含有されている 低分子量のトリペプチドで，蛋白，DNA 合成，細胞内 輸送, 細胞内還元, 細胞保護といった重要な働きに, 直 接的あるいは間接的に関与していることが知られてい る32)。なかでも，細胞保護作用は活性酸素化合物を生 成する組織比いて, 特重要とされている.内耳, 特 に蝸牛は好気性酸化が盛んであり, 過酸化水素, あるい はフリーラジカルの様な細胞障害性に働く多くの活性酸 素化合物を生成する ${ }^{33)}$. 通常, 生体内に括いて, 例えば 
血管条の中間細胞では, カタラーゼを含むペルオキシ ゾームが存在し, 好気性代謝により生成される過酸化水 素を失活させている34)ように，蝸牛中に存在するグル タチオンを中心とする酵素が活性酸素化合物の解毒を行 い，蝸牛を保護していると考吕られる．しかしながら， 何らかの原因で，この解毒作用が障害された場合, 内耳 障害が発現すると考兄られる. Hoffman ら ${ }^{12)}$ は, 細胞 内のグルタチオンを減少させた場合, アミノ配糖体系薬 剤の耳毒性が増強されることを明らかにし，グルタチオ ンが蝸牛内での細胞保護に働いている可能性があること を報告し, 実験的にも, ラジカル捕獲剤がカナマイシン の耳毒性を軽減することより ${ }^{35)}$ ，耳毒性関するグルタ チオンの関与は明らかなものとなってきている. 実際, 耳毒性薬剤のいくつかは，グルタチオンを枯渴させたり あるいはグルタチオン経路の酵素を失活させると考兄ら れて招り，このグルタチオンの減少は，耳毒性薬剤ある いはその代謝産物, とくにフリーラジカルによる蝸牛の 受傷性を増すとされている。

以上の結果をもとにした今回の研究により, アミカシ ンによる蝸牛有毛細胞の障害は, グルタチオンにより有 意に軽減されることが明らかとなった。グルタチオンの 耳毒性に対する影響について, Garetz ら ${ }^{13)}$ は, in vivo で, 単離外有毛細胞のゲンタマイシンによる障害性がグ ルタチオンの存在下に有意に抑制されること, in vitro で，ゲンタマイシンによる聴力低下がグルタチオンによ り軽減することを報告しているが，今回の結果により， 組織学的にもグルタチオンはアミノ配糖体系薬剤の耳毒 性を有意に軽減することが証明された。さらに今回, グ ルタチオンは有毛細胞聴毛の完全脱落 (Grade 3) といっ た有毛細胞の高度な障害を特に軽減させることが明らか となった. Grade 1 あるいは Grade 2 といった有毛細胞 聴毛の部分的障害はアミカシンの膜に対する直接的な作 用によっても生じることが知られている15)が，Grade 3 のような聴毛のすべて, あるいは細胞体も含めた高度障 害には前述したようにアミカシンの毒性代謝産物による 作用が大きく関与していると思われる。矢机ゆえ, 今回 の実験結果はグルタチオンによりアミカシンの代謝産物 による障害が軽減されたことを示しているものと考光ら れる。すなわち，アミノ配糖体系薬剤による永続的な耳 毒性はアミノ配糖体系薬剤の耳毒性代謝産物により生じ, グルタチオンが，その上らな永続的な内耳障害を予防す る可能性を表しているものと考兄られる. 以上のことか
ら,グルタチオンは, 臨床的にもアミノ配糖体系薬剤の 耳毒性の予防といら目的に大きく役立つ可能性があるも のと考觉れた。

\section{結 語}

アミノ配糖体系薬剤の 1 種であるアミカシンによる蝸 牛コルチ器有毛細胞の障害は, グルタチオンにより有意 に軽減されることが明らかとなった，その機序は，グル タチオンによるアミカシン代謝産物の解毒作用以上るも のと考光られた．このことにより臨床的にアミノ配糖体 系薬剤の永続的な耳毒性が，グルタチオンにより軽減さ れる可能性が示唆された.

稿を終えるにあたり，御指導ならびに御校閲を賜りました恩 師, 原田康夫広島大学長に深甚なる謝意を表します。また, 本 研究に際し, 絶觉ず御指導と御助言を戴きました夜陣紘治広島 大学医学部耳鼻咽喉科学教授に深く感謝致します。ささらに, 多 くのご助言をいただいた鈴木 衞助教授，平川勝洋講師をはじ めとする広島大学医学部耳鼻咽喉科学教室員と, 工田昌矢広島 総合病院耳鼻咽喉科主任部長潐謝の意を表します.

\section{参考文献}

1) Wersäl J : Structural damage to the organ of Corti and the vestibular epithelia caused by aminoglycoside antibiotics in the guinea pig. Aminoglycoside Ototoxicity (ed by Lerner SA, et al). pp 197 214, Little, Brown and Company, Boston, 1981.

2 ) Wersäl J : Recent otological evaluation of aminoglycoside antibiotics. J Antimicrob Chemother Suppl $13: 31 \sim 36$, 1984 .

3 ) 西田 功: 硫酸イセパマイシンの耳毒性について. 耳鼻臨 床 $83: 629 \sim 638,1990$.

4 ) Bamonte F, Barbara M, Dianisotti S, et al : Effect of dosing schedule on aminoglycoside ototoxicity in guinea pigs. J Drug Dev $1: 97 \sim 108,1988$.

5 ) Shankar A and Sharma SD : Gentamicin as once-daily dose therapy in recurrent urinary tract infections in children. Curr Ther Res $41:$ 599 603, 1987.

6 ) Cohen B, Saginur R, Clecner B, et al : Double-blind comparative trial of once-vs twice-daily netilmicin therapy in severe acute urinary tract infections. Curr Ther Res 38 : $880 \sim 884,1985$.

7 ）大梘好正, 大谷 璇, 相川 通, 他: アミノ配糖体抗生剂 による聴器障害に対する Fosfomycin の軽減作用とその機 序に関する研究. 日耳鼻 $86: 1488 \sim 1496,1983$.

8 ) 秋定 健, 折田洋造 : カナマイシン聴器毒性に対するセフ 
ァランチンの効果. Ear Res Jpn $19: 250 \sim 252,1988$.

9 ) 斎藤武久, 斎藤 等, 真鍋恭弘, 他：ヘパリンの特殊経路 投与によるアミノ配糖体抗生剂耳毒性軽減に関する実験的 研究. Ear Res Jpn 19 : 253 255, 1988.

10) Hulka GF, Prazma J, Brownlee RE, et al : Use of poly-Laspartic acid to inhibit aminoglycoside cochlear ototoxicity. Am J Otol $14:$ 352 356, 1993.

11) Zenner HP, Keiner $S$ and Zimmermann $U$ : Specific glutathione-SH inhibition of toxic effects of metabolized gentamicin on isolated guinea pig hair cells. Eur Arch Otorhinolaryngol $251:$ 84 90, 1994.

12) Hoffman DW, Whitworth CA, Jones-King KL, et al : Potentiation of ototoxicity by glutathione depletion. Ann Otol Rhinol Laryngol $97:$ 36 41, 1988.

13) Garetz SL, Rhee DJ and Schacht L : Attenuation of gentamicin ototoxicity by glutathione. 29th Inner Ear Biology Workshop. Abstract. pp 74, 1992.

14) Johansson B, Fredelius L, Perols $\mathrm{O}$, et al : Compound action potential threshold shift and cochlear damage in guinea pigs after pure tone acoustic trauma. Hearing Loss and Dizziness (ed by Nomura Y). pp 139 149, IgakuShoin, Tokyo $\cdot$ New York, 1985.

15) Crann SH, Huang MY, Mclaren JD, et al : Formation of a toxic metabolite from gentamicin by a hepatic cytosolic fraction. Biochem Pharmacol 43 : 1835 1839, 1992.

16) Huang MY and Schacht J : Formation of a cytotoxic metabolite from gentamicin by liver. Biochem Parmacol $40: 11 \sim 14,1990$.

17) Schacht J : Molecular mechanisms of drug-induced hearing loss. Hear Res 22 : 297 304, 1986.

18) Duron D, Zajic G, Aran JM, et al : Aminoglycoside antibiotics impair calcium-entry but not viability and motility of cochlear outer hair cells. J Neurosci Res $24: 338 \sim 346$, 1989.

19) Kroese A, Das A, Hudspeth A : Blockage of the transduction channels of hair cells in the bullfrog sacculus by aminoglycoside antibiotics. Hear Res $37: 203 \sim 217,1989$.

20) Schacht $J$ : Isolation of an aminoglycoside receptor from guinea pig inner ear tissue and kidney. Arch Otorhinolaryngol $224: 129 \sim 134,1979$.

21）世良公志：ゲンタマイシンの前庭器・神経節に及ぼす影響. 耳鼻臨床 $82 ： 1293 \sim 1306,1989$.

22) Hawkins JE : Drug ototoxicity. Handbook of Sensory Physiology (ed by Keidel WD and Neff WD). pp 707 748, Springer, New York, 1976.

23) Whelton $\mathrm{A}$ : Treatment of gram-negative infection in pa- tients with renal impairment; new alternatives to aminoglycosides. J Clin Pharmacol 28 : 866 878, 1988.

24) Hori $R$, Yamamoto $K$, Saito $H$, et al : Effect of aminoglycoside antibiotics on cellular functions of kidney epithelial cell line (LLC-PK1); a model system for aminoglycoside nephrotoxicity. J Pharmacol Exp Ther $230: 742 \sim 748,1984$.

25) Sande MA and Mandell GL : Antimicrobial agents. The Aminoglycosides, The Pharmacological Basis of Therapeutics (ed by Goodman AG, et al). pp 1150 1169, Macmillian, New York, 1985.

26) Wilson TW, Mahon WA, Inaba $T$, et al : Elimination of tritiated gentamicin in normal human subjects and in patients with severely impaired renal function. Clin Pharmacol Ther $14: 815 \sim 822,1973$.

27) Huang MY and Schacht J : Non-microsomal metabolites of aminoglycosides are cytotoxic to cochlear outer hair cells. Otolaryngol Head Neck Surg 105 : 191, 1991.

28) Ziegler DM : Flavin-containing monooxygenases; catalytic mechanism and substrate specificities. Drug Metab Rev $19: 1 \sim 32,1988$.

29) Takada A and Schacht J : Calcium antagonism and reversibility of gentamicin-induced loss of cochlear microphonics in the guinea pig. Hear Res $8: 179 \sim 186,1982$.

30) Anniko M, Takada A and Schacht J : Comparative ototoxicities of gentamicin and netilmicin in three model systems. Am J Otolaryngol 3 : 422 433, 1982.

31) Nelson SD and Gordon WP : Mammalian drug metabolism. J Nat Prod $46:$ 71 78, 1983.

32) Meister A and Anderson ME : Glutathione. Ann Rev Biochem 52 : 711 760, 1983.

33) Pierson MG and Gray BH : Superoxide dismutase activity in the cochlea. Hear Res $6: 141 \sim 151,1982$.

34) Spector GJ and Carr C : The ultrastructural cytochemistry of peroxisomes in the guinea pig cochlea; a metabolic hypothesis for the stria vascularis. Laryngoscope $89: 1 \sim$ 38, 1979 ,

35) Pierson $M$ and Mollear A : Prophylaxis of kanamycin-induced ototoxicity by a radioprotectant, Hear Res 4 : 79 87, 1981.

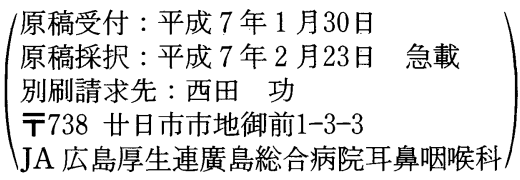

